\title{
Characteristics of rambutan (Nephelium lappaceum $L$.) seed fat fractions and their potential application as cocoa butter improver
}

\author{
Azzatul, F., *Jahurul, M.H.A., Norliza, J., Norazlina, M.R., Hasmadi, M., Sharifudin, M.S., \\ Matanjun, P. and Lee, J.S. \\ Faculty of Food Science and Nutrition, Universiti Malaysia Sabah, 88400 Kota Kinabalu, Sabah, Malaysia
}

\author{
Article history: \\ Received: 11 December 2019 \\ Received in revised form: 19 \\ January 2020 \\ Accepted: 23 January 2020 \\ Available Online: 17 \\ February 2020
}

Keywords:

Rambutan seed fat,

Fractionation,

Fatty acids,

Solid fat content,

Cocoa butter

DOI:

https://doi.org/10.26656/fr.2017.4(3).413

\begin{abstract}
The utilization of rambutan seed (Nephelium Lappaceum L.) to produce fat (RSF) and its fractionation could be one of the solutions for better waste management and for ensuring its sustainable utilization. In this study, RSF was fractionated by two-stage acetone fractionation and their physicochemical properties such as fatty acid compositions, iodine value (IV), free fatty acid (FFA), slip melting point (SMP), and solid fat content (SFC) were investigated. The solid fraction-III $\left(\mathrm{F}_{2}-\mathrm{S}\right)$ exhibited the highest SMP $\left(49.03^{\circ} \mathrm{C}\right)$ and lowest IV $\left(27.57 \mathrm{~g} \mathrm{I}_{2} / 100 \mathrm{~g}\right)$. The major fatty acids in all solid fractions were stearic (15.1$21.6 \%$ ), oleic $(25.0-35.5 \%)$, and arachidic $(42.7-46.9 \%)$ acids. The $\mathrm{SFC}$ of $\mathrm{F}_{2}-\mathrm{S}$ at $20^{\circ} \mathrm{C}$ $(78.57 \%)$ and $35^{\circ} \mathrm{C}(22.95 \%)$ were found to be higher than solid fraction-I $\left(\mathrm{F}_{1}-\mathrm{S}\right)$, indicating a harder solid fraction. This study revealed that by performing fractionation of RSF, a cocoa butter improvers (CBI) could be prepared by blending them with other fats that have the potential to be utilized in chocolate manufacturing in tropical countries.
\end{abstract}

\section{Introduction}

The modification of fats and oils is an important and useful technique to improve their physicochemical and thermal properties. This technique including blending, hydrogenation, fractionation, and chemical and enzymatic interesterification are used to produce fats for margarine, confectionery, cosmetic, and chemical industries (Timms, 2005; Gibon, 2006; Momeny et al., 2013; Kang et al., 2013; Jin et al., 2016; Kadivar et al., 2016; Lakum and Sonwai, 2018). Solvent fractionation is applied to produce structural lipids such as hard fats (high-melting-point triacylglycerols), polyunsaturated fatty acid-rich oil, creams, and margarines due to the high separation efficiency and yield of aimed fractions with sharper melting properties (Gibon, 2006; Kellens et al., 2007; Mu et al., 2016; Jin et al., 2016). For example, palm oil is fractionated into palm stearin and liquid and is the most widely fractionated oil worldwide (Senanayake and Shahidi, 2005; Gibon, 2006). Meanwhile, these palm oil fractions have been used to prepare wide variety of food products, especially confectionery products (Jahurul, Zaidul, Norulaini, Sahena, Kamaruzzaman et al., 2014; Jahurul, Zaidul, Norulaini, Sahena, Abedin et al., 2014; Lakum and Sonwai, 2018).

Cocoa butter (CB) for instance, is a high-priced constituent and crucial ingredient in chocolate formulations, and responsible for the melting behavior and glossy texture of chocolate products (Jin et al., 2016; Kadivar et al., 2016; Jia et al., 2019). Despite being the most ideal constituent and ingredients in chocolate and other confectionery products, the low melting point of CB causes the products, especially chocolate to melt easily in subtropical and tropical areas (Shahidi, 2005). Furthermore, demand for chocolate products keeps increasing despite the high-cost and uncertainty in the supply of $\mathrm{CB}$ increasing the interests among manufacturers and researchers to find for alternatives such as cocoa butter equivalents (CBE) (Tchobo et al., 2009). Cocoa butter equivalents (CBEs) are vegetable fats that possess similar physical and chemical properties with CB (Smith, 2001). CBE is specifically designed to include a structure of glyceride identical to that of CB. In mixtures for the manufacturing of chocolate, their properties are supposed to be identical and consistent with CB. CBEs are classified into two subgroups, which are cocoa butter extenders (CBEXs) and cocoa butter improvers CBIs (Lipp and Anklam, 1998). CBEXs usually is not compatible to be mixed in any proportion with $\mathrm{CB}$, whereas $\mathrm{CBIs}$ are more comparable to CBEs, which contain higher amounts of solid triglycerides and are commonly used to improve soft cocoa butter due to this characteristic (Naik and Kumar, 2014).

Rambutan (Nephelium lappaceum L.) is one of the 
most known seasonal fruit in Southeast Asia for its sweet -sensational taste and noticeable appearance (Sirisompong et al., 2011; Issara et al., 2014). It can be freshly consumed and processed for industrial commercialization as jams, juices, spreads, jellies, canned fruit, syrup, and marmalades (Sonwai and Ponprachanuvut, 2012; Lourith et al., 2016). Rambutan seed is considered as a waste in rambutan canning manufactures with a noteworthy value approximately 94,500 tons/year in Thailand, Indonesia, and Malaysia (Norlia et al., 2011). After direct consumption or industrial processing, the seeds and peels are discarded as a co-product that can raise severe environmental issues and cause economic losses if not managed effectively (Solís-Fuentes et al., 2010; Chai et al., 2018). This extensive value has become an issue that needs to be solved. Meanwhile, RSF is used for making candles, soaps, and fuel manufacturing. Moreover, it is also a possible source of natural edible fat such as confectionery products that would be beneficial in the food industry (Solís-Fuentes et al., 2010). However, modification of the physicochemical and thermal properties of RSF to become the new alternative to be used in the food industry, can contribute to industrial economic gains and become one of the solutions to the fruit wastes management. Therefore, this study was aimed to provide new information about two-stage acetone fractionation of RSF. The physicochemical properties such as fatty acids, iodine value (IV), free fatty acid (FFA), slip melting point (SMP), and solid fat content (SFC) of each RSF fractions were also determined.

\section{Material and methods}

\subsection{Preparation of rambutan seed powder}

Rambutan fruit (mature, red in colour) was purchased from local market Papar, Sabah. The peels and flesh were removed using a household knife and then were manually washed and cleaned. The seeds were cut into smaller pieces and then air-dried in an oven at $50^{\circ} \mathrm{C}$ for $18 \mathrm{~h}$. The dried seeds were then finely ground into powder using a warring blender (Pensonic, Malaysia), stored in zip-lock bags. The powder was stored in a desiccator for further analysis.

\subsection{Extraction of RSF using Soxhlet}

The extraction of RSF was performed using Soxhlet extractor. Approximately, $100 \mathrm{~g}$ of rambutan seed powder was transferred into $2 \mathrm{~L}$ Soxhlet extractor (Favorit, Malaysia) and the extraction was performed using $n$-hexane as a solvent for $8 \mathrm{~h}$. The fat was recovered using rotary vacuum evaporator (Heidolph, Germany) and then dried in an oven at $60^{\circ} \mathrm{C}$ for $2 \mathrm{hrs}$.
The extracted fat was then weighed and stored at $-20^{\circ} \mathrm{C}$ for further analysis. The total RSF fat yield was obtained as a percentage.

\subsection{Fractionation of $R S F$}

Fractionation of RSF was performed as two-stage acetone based on the method developed by Jin et al. (2016) with slight modification. The fractionation process is shown in Figure 1. Approximately, $100 \mathrm{~g}$ of RSF was melted uniformly and mixed with acetone at a ratio of $1: 5(\mathrm{w} / \mathrm{v})$ and left for $8 \mathrm{~h}$ to crystalize (at $\left.18^{\circ} \mathrm{C}\right)$. The crystalized (fraction-I) and liquid (fraction-II) fractions then separated using filter paper under vacuum and dried by rotary evaporator (Heidolph, Germany). The crystallized fractions were further cooled to $12^{\circ} \mathrm{C}$ and kept for 40 mins. The second solid fraction (fractionIII) was obtained after separation with the second liquid fraction (fraction-IV) by filtering the fraction (cool at $5^{\circ} \mathrm{C}$ and keep for $8 \mathrm{hrs}$ ). All fractions were separated and dried by the same method.

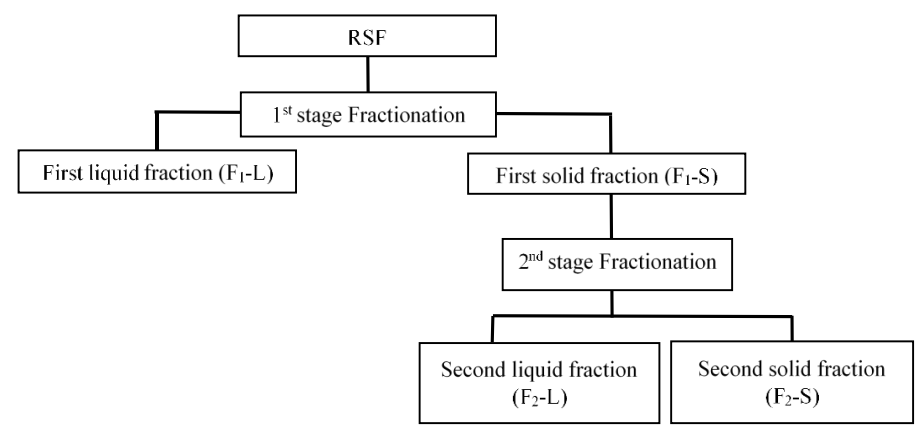

Figure 1. Rambutan seed fat fractions produced by two-stage acetone fractionation.

\subsection{Determination of physicochemical properties of RSF and its fractions}

The physicochemical properties of RSF and its fractions (fatty acids, SMP, IV, and FFA) were analyzed according to the official method established by American Oil Chemists' Society (2003).

\subsection{Determination of fatty acids by GC-FID}

Fatty acids were determined by GasChromatography with flame ionization (GC-FID) detector according to the previous study (Jahurul, Zaidul, Norulaini, Saleha, Kamaruzzaman et al., 2014). The GCFID (Agilent, USA) with a BPX 70 capillary column was used with a DB-23 (J\&W Scientific) capillary column. The carrier gas used was helium that has a flow rate of $1.5 \mathrm{ml} /$ minute. The operation of the split/splitless injector was set at $25^{\circ} \mathrm{C}$ with the split rate of $100: 1$. The interface temperature of GC-FID was adjusted to $220^{\circ} \mathrm{C}$ with ion source temperature at $200^{\circ} \mathrm{C}$. The oven temperature of $\mathrm{GC}$ was set at $80^{\circ} \mathrm{C}$ with holding time of 
2 mins, ramped to $230^{\circ} \mathrm{C}$ at the rate of $2.5^{\circ} \mathrm{C} / \mathrm{min}$ with holding time up to 5 minutes. Fatty acid compositions calculated were based on percentage peak area of the GC chromatogram.

\subsection{Determination of solid fat content (SFC)}

The SFC of crude RSF and its fractions was determined by pNMR (Bruker minispec mq20 NMR analyzer) according to Fiebig and Lüttke (2003). RSF and its fractions were tempered at $60^{\circ} \mathrm{C}$ for 5 mins (or longer), followed by chilling at $0^{\circ} \mathrm{C}$ for 90 mins and kept at the desired temperatures for 60 to 65 mins prior to measurements. The melting, chilling and holding of the test samples were carried out in the pre-equilibrated thermostat bath. The temperature ranges used for the determination of SFC were $10-40^{\circ} \mathrm{C}$.

\subsection{Statistical analysis}

All the experiments were conducted in triplicates and duplicates reported as mean \pm standard deviation. Twoway analysis of variance (ANOVA) and Tukey Honest Significance Difference (HSD) test was applied at a $95 \%$ confidence interval using the SPSS program version 25.0. The correlation between each analysis was calculated by multiple linear regression analysis.

\section{Results and discussion}

\subsection{Extraction and yield}

Table 1 shows the total yield of crude RSF and its fractions produced by two-stage fractionation. Solvent fractionation process led to nearly complete separation of the high melting solid fractions from crude RSF. The total fat content $(34.10 \%)$ of crude RSF obtained in this study was comparable with previous studies which ranged from 32.60 - 39.13\% (Solís-Fuentes et al., 2010; Sirisompong et al., 2011; Lourith et al., 2016; Chai et al., 2018; Chai et al., 2019). The first stage crystallization process of crude RSF yielded first solid fraction $\left(\mathrm{F}_{1}-\mathrm{S}\right)(53.09 \%)$ that was significantly $(\mathrm{p}>0.05)$ higher than the first liquid fraction $\left(\mathrm{F}_{1}-\mathrm{L}\right)(46.91 \%)$. Further fractionation on the first solid fraction $\left(\mathrm{F}_{1}-\mathrm{S}\right)$ under the same conditions produced more saturated fats. The second stage fractionation from the first solid fraction $\left(\mathrm{F}_{1}-\mathrm{S}\right)$ produced the second solid $\left(\mathrm{F}_{2}-\mathrm{S}\right)$ and liquid $\left(\mathrm{F}_{2}-\mathrm{L}\right)$ fractions yielded $56.96 \%$ and $43.04 \%$, respectively. The results corresponded with the previous study conducted by Jin, Wang, Su et al. (2017), where the yield of mango seed fat solid fractions decreased after first and second stages of fractionation due to the solid fractions became more saturated. The presence of high melting saturated fatty acids (SFAs) which were mainly arachidic and stearic acids in $\mathrm{F}_{1}-\mathrm{S}$ resulted in gradual precipitation of SFAs from the liquids because of the effect of low-temperature crystallization, hence more of solid fractions yielded (Latip et al., 2013). Meanwhile, the liquid fractions were found to be easily melted at $<28^{\circ} \mathrm{C}$ due to the presence of low melting unsaturated fatty acids (USFAs) which were mainly oleic and linoleic acids causing less production of solid fractions at low temperature of crystallization process in the second stage of fractionation from $\mathrm{F}_{1}-\mathrm{L}$ (Jin, Wang, Su et al., 2017)

Table 1. Total yields of crude RSF and its fractions

\begin{tabular}{lc}
\hline \multicolumn{1}{c}{ Sample } & Yield $(\%)$ \\
\hline RSF & $34.10 \pm 0.07^{\mathrm{c}}$ \\
First Stage of fractionation (From RSF) & \\
\hline $\mathrm{F}_{1}-\mathrm{S}$ (First solid fraction) & $53.09 \pm 0.04^{\mathrm{b}}$ \\
$\mathrm{F}_{1}-\mathrm{L}$ (First liquid fraction) & $46.91 \pm 0.03^{\mathrm{c}}$ \\
Second Stage of Fractionation (From $\left.\mathrm{F}_{1}-\mathrm{S}\right)$ & \\
\hline $\mathrm{F}_{2}-\mathrm{S}$ (Second solid fraction) & $56.96 \pm 0.04^{\mathrm{a}}$ \\
$\mathrm{F}_{2}-\mathrm{L}$ (Second liquid fraction) & $43.04 \pm 0.05^{\mathrm{c}}$ \\
\hline
\end{tabular}

Mean values \pm SD of triplicates; means with different letters are significantly different $(\mathrm{p}<0.05)$ as measured by Tukey's test.

\subsection{Fatty acids composition}

The fatty acids of crude RSF and its fractions are shown in Table 2. Some of the gas chromatograms of RSF and its solid fraction are shown in Figure 2. The major fatty acids found in crude RSF were arachidic $\left(\mathrm{C}_{20: 0}\right)(40.9 \%)$, oleic $\left(\mathrm{C}_{18: 1}\right)(40.3 \%)$ and stearic $\left(\mathrm{C}_{18: 0}\right)$ $(8.6 \%)$ acids. These three fatty acids constituted approximately $89.8 \%$ of the total fatty acids. These values were comparable with the values reported by (Solís-Fuentes et al., 2010; Sirisompong et al., 2011; Yanty et al., 2013). RSF also contained significant quantities of palmitic (3.8\%), linolenic (3.2\%), and behenic (4.5\%) acids. These fatty acids affected the physicochemical and thermal characteristics of RSF and its fractions.

Solvent fractionation is mostly used by researchers due to the high separation efficiency and purity for diverse applications (Gibon 2006; Kang et al., 2013; Jin et al., 2016; Jin, Wang, Su et al., 2017). Fractions with narrower and better properties than crude RSF can be obtained through solvent fractionation. It was expected that due to the fractionation process, the USFAs would be concentrated in the liquid fractions and significantly reduced in the solid fractions. A significant increasing and decreasing trends were observed among the fatty acids in the fractions because of the fractionation process. It was found that SFAs such as $\mathrm{C}_{20: 0}(46.9 \%)$ and $\mathrm{C}_{18: 0}(21.6 \%)$ contents in $\mathrm{F}_{2}-\mathrm{S}$ were significantly $(p>0.05)$ higher than $F_{1}-S(42.7$ and $15.1 \%)$ and crude RSF (40.9 and 8.6\%). On the other hand, the USFAs $\left(\mathrm{C}_{18: 1}\right.$ and $\left.\mathrm{C}_{18: 2}\right)$ in both liquid fraction-II and IV $\left(\mathrm{F}_{1}-\mathrm{L}\right.$ . 
Table 2. Fatty acid composition (\%) of rambutan seed fat and its fractions

\begin{tabular}{|c|c|c|c|c|c|c|}
\hline \multirow{2}{*}{ Fatty acids } & \multirow{2}{*}{ RSF (Crude) } & \multicolumn{2}{|c|}{ First stage of fractionation from } & \multicolumn{2}{|c|}{ Second stage of fractionation } & \multirow{2}{*}{ Cocoa butter ${ }^{1,2,3}$} \\
\hline & & $\mathrm{F}_{1}-\mathrm{S}$ (Solid) & $\mathrm{F}_{1}-\mathrm{L}$ (Liquid) & $\mathrm{F}_{2}-\mathrm{S}$ (Solid) & $\mathrm{F}_{2}-\mathrm{L}$ (Liquid) & \\
\hline $\mathrm{C}_{16: 0}$ & $3.8 \pm 0.5^{\mathrm{c}}$ & $2.5 \pm 0.4^{\mathrm{d}}$ & $5.7 \pm 0.1^{\mathrm{a}}$ & $2.0 \pm 0.9^{\mathrm{e}}$ & $4.2 \pm 0.2^{\mathrm{b}}$ & $25.3-28.1$ \\
\hline $\mathrm{C}_{18: 0}$ & $8.6 \pm 0.3^{c}$ & $15.1 \pm 0.9^{\mathrm{b}}$ & $3.9 \pm 0.1^{\mathrm{e}}$ & $21.6 \pm 0.1^{\mathrm{a}}$ & $6.9 \pm 0.8^{\mathrm{d}}$ & $34.5-37.8$ \\
\hline $\mathrm{C}_{18: 1}$ & $40.3 \pm 0.3^{\mathrm{c}}$ & $35.5 \pm 1.3^{d}$ & $51.7 \pm 0.0^{\mathrm{a}}$ & $25.0 \pm 0.5^{\mathrm{e}}$ & $42.2 \pm 0.0^{\mathrm{b}}$ & $32.8-33.2$ \\
\hline $\mathrm{C}_{18: 2}$ & $3.2 \pm 0.0^{\mathrm{c}}$ & $2.2 \pm 0.7^{\mathrm{d}}$ & $3.7 \pm 0.3^{\mathrm{a}}$ & $1.9 \pm 1.0^{\mathrm{e}}$ & $3.6 \pm 0.1^{\mathrm{b}}$ & 2.9 \\
\hline $\mathrm{C}_{20: 0}$ & $40.9 \pm 0.1^{\mathrm{c}}$ & $42.7 \pm 0.0^{\mathrm{b}}$ & $33.2 \pm 0.3^{\mathrm{e}}$ & $46.9 \pm 0.0^{\mathrm{a}}$ & $36.8 \pm 0.2^{\mathrm{d}}$ & 1 \\
\hline $\mathrm{C}_{22}$ & $4.5 \pm 0.1^{\mathrm{d}}$ & $4.93 \pm 0.1^{\mathrm{b}}$ & $2.9 \pm 0.1^{\mathrm{e}}$ & $5.3 \pm 0.2^{\mathrm{a}}$ & $4.6 \pm 0.3^{\mathrm{c}}$ & 0 \\
\hline SFAs & $56.8 \pm 0.0^{\mathrm{c}}$ & $64.3 \pm 0.5^{\mathrm{b}}$ & $45.3 \pm 0.2^{\mathrm{e}}$ & $74.7 \pm 0.1^{\mathrm{a}}$ & $49.8 \pm 0.0^{\mathrm{d}}$ & $57-64$ \\
\hline UFAs & $43.2 \pm 0.1^{\mathrm{c}}$ & $36.4 \pm 0.2^{\mathrm{d}}$ & $54.9 \pm 0.0^{\mathrm{a}}$ & $25.6 \pm 0.2^{\mathrm{e}}$ & $50.3 \pm 0.1^{\mathrm{b}}$ & $36-43$ \\
\hline
\end{tabular}

Mean values \pm SD of duplicates; means with different letters in the same row are significantly different $(p<0.05)$ as measured by Tukey's test.

${ }^{1}$ Kadivar et al. (2016); ${ }^{2}$ Yanty et al. (2012); ${ }^{3}$ Gunstone (2011)
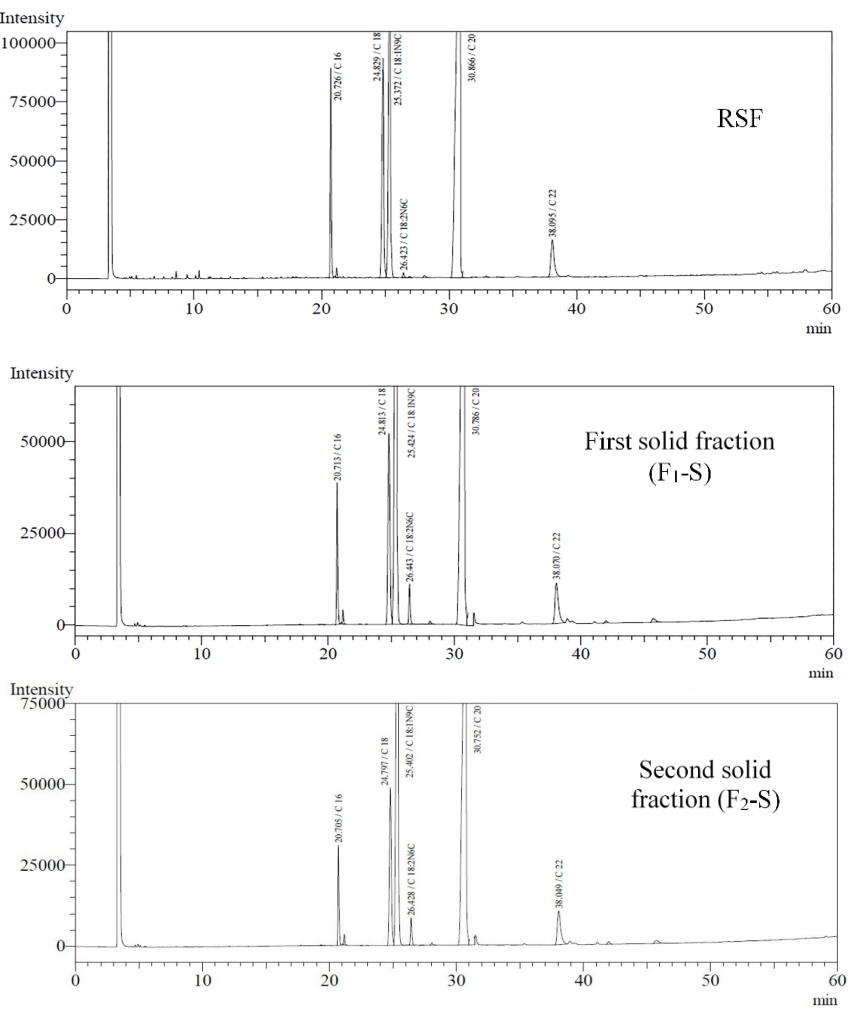

Figure 2. GC chromatogram of fatty acid methyl esters of RSF and its solid fraction-I and III.

and $\left.\mathrm{F}_{2}-\mathrm{L}\right)$ were significantly $(\mathrm{p}>0.05)$ increased from crude RSF. However, $\mathrm{C}_{18: 1}$ and $\mathrm{C}_{18: 2}$ acids of liquid fraction-II $\left(\mathrm{F}_{1}-\mathrm{L}\right)(51.7$ and $3.7 \%)$ were found to be higher than liquid fraction-IV $\left(\mathrm{F}_{2}-\mathrm{L}\right)(42.2$ and $3.6 \%)$. The $\mathrm{C}_{16: 0}$ content in solid fraction-I and III (2.5 and $2.0 \%)$ were found to be significantly $(p>0.05)$ lower than crude RSF. Meanwhile, the $\mathrm{C}_{16: 0}$ content was increased in both $\mathrm{F}_{1}-\mathrm{L}$ and $\mathrm{F}_{2}-\mathrm{L}$ (5.7 and 4.2\%). The results were comparable with previous study performed by Jin, Wang, Su et al. (2017), where the $\mathrm{C}_{16: 0}$ content managed to be decreased in solid fractions but increased in all liquid fractions. The authors also reported that USFAs $\left(\mathrm{C}_{18: 1}\right.$ and $\left.\mathrm{C}_{18: 2}\right)$ in liquid fractions and SFAs $\left(\mathrm{C}_{18: 0}\right.$ and $\mathrm{C}_{20}$ ) in solid fractions were higher than crude mango seed fat. Similar findings were observed by Kang et al.
(2013), who fractionated palm stearin and found to have increasing trends for USFAs $\left(\mathrm{C}_{18: 1}\right.$ and $\left.\mathrm{C}_{18: 2}\right)$ in liquid fractions. Gunstone (2011) stated that the major fatty acids contained in most CBIs are palmitic acid, stearic acid and oleic acid, similar to that of $\mathrm{CB}$, which contributed $57-64 \%$ to the total saturated fatty acid present in CB and unsaturated fatty acid about $36-43 \%$. The results in Table 2 demonstrated that the total of saturated and unsaturated fatty acids of crude RSF and its fractions were quite different based on the amount of $\mathrm{C}_{16: 0}, \mathrm{C}_{18: 0}$ and $\mathrm{C}_{20}$. However, they are still comparable with $\mathrm{CB}$. It might serve as a novel source of CBI due to the presence of high melting fatty acid such as $\mathrm{C}_{20: 0}$ which can help to increase the hardness of $\mathrm{CB}$ to be used as confectionary products ingredients in the country with tropical climates. The unique fatty acid composition of the fractions demonstrated that they could be widely used as a good value-adding alternative in cocoa butter to improve the softness of cocoa butter.

\subsection{Physicochemical properties}

Table 3 shows the IV, SMP, and FFA of RSF and its fractions. The study of IV is crucial in determining the degree of unsaturation and hardness of oils and fats (Jahurul, Zaidul, Norulaini, Saleha, Kamaruzzaman et al., 2014). High IV indicated higher unsaturation in the fats or oils. In this study, the IV (45.51 $\mathrm{g} \mathrm{I}_{2} / 100 \mathrm{~g}$ fat) and SMP $\left(41.57^{\circ} \mathrm{C}\right)$ of crude RSF were within the range reported by Solís-Fuentes et al. (2010), Sirisompong et al. (2011), Sonwai et al. (2012), Yanty et al. (2013), and Chai et al. $(2018,2019)$.

IVs of all solid fractions $\left(\mathrm{F}_{1}-\mathrm{S}\right.$ and $\left.\mathrm{F}_{2}-\mathrm{S}\right)$ ranged from $27.57-35.14 \mathrm{~g} \mathrm{I}_{2} / 100 \mathrm{~g}$ fat which was significantly $(p>0.05)$ lower than crude RSF. However, IVs of all liquid fractions $\left(\mathrm{F}_{1}-\mathrm{L}\right.$ and $\left.\mathrm{F}_{2}-\mathrm{L}\right)$ ranged from 47.22 $48.49 \mathrm{~g} \mathrm{I}_{2} / 100 \mathrm{~g}$ fat which was significantly $(\mathrm{p}>0.05)$ higher than crude RSF. The SMP of solid fraction-I 
Table 3. Physicochemical properties of crude RSF and its fractions

\begin{tabular}{|c|c|c|c|c|}
\hline Samples & $\mathrm{IV}\left(\mathrm{g} \mathrm{I}_{2} / 100 \mathrm{~g}\right.$ fat $)$ & $\operatorname{SMP}\left({ }^{\circ} \mathrm{C}\right)$ & FFA $(\%)$ as oleic acid & FFA $(\%)$ as palmitic acid \\
\hline RSF & $45.51 \pm 0.04^{\mathrm{c}}$ & $41.57 \pm 0.12^{\mathrm{c}}$ & $2.94 \pm 0.12^{\mathrm{a}}$ & - \\
\hline \multicolumn{5}{|c|}{ First Stage of fractionation (From RSF) } \\
\hline $\mathrm{F}_{1}-\mathrm{S}$ (First solid fraction) & $35.14 \pm 0.04^{\mathrm{d}}$ & $45.57 \pm 0.11^{b}$ & $2.03 \pm 0.11^{\mathrm{c}}$ & - \\
\hline $\mathrm{F}_{1}-\mathrm{L}$ (First liquid fraction) & $48.49 \pm 0.13^{\mathrm{a}}$ & $25.57 \pm 0.11^{\mathrm{e}}$ & - & $1.87 \pm 0.11^{\mathrm{a}}$ \\
\hline \multicolumn{5}{|c|}{ Second Stage of Fractionation (From $\left.\mathrm{F}_{1}-\mathrm{S}\right)$} \\
\hline $\mathrm{F}_{2}-\mathrm{S}$ (Second solid fraction) & $27.57 \pm 0.03^{\mathrm{e}}$ & $49.03 \pm 0.06^{\mathrm{a}}$ & $2.25 \pm 0.12^{\mathrm{b}}$ & - \\
\hline $\mathrm{F}_{2}-\mathrm{L}$ (Second liquid fraction) & $47.22 \pm 0.17^{b}$ & $27.43 \pm 0.09^{\mathrm{d}}$ & - & $1.75 \pm 0.07^{b}$ \\
\hline Cocoa butter ${ }^{1-5}$ & $34.0-37.9$ & $20.0-37.0$ & - & $1.62-2.08 \pm 0.02$ \\
\hline
\end{tabular}

RSF, rambutan seed fat; IV, iodine value; SMP, slip melting point; FFA, free fatty acid.

Mean values $\pm \mathrm{SD}$ of triplicates; means that do not share the same letter in the same column are significantly different $(p<0.05)$ as measured by Tukey's test.

${ }^{1}$ Muchiri et al. (2012); ${ }^{2}$ Yanty et al. (2012); ${ }^{3}$ Hamid and Damit (2004); ${ }^{4}$ Timms (2005); ${ }^{5}$ Foubert et al. (2004)

$\left(45.57^{\circ} \mathrm{C}\right)$ and solid fraction-II $\left(49.03^{\circ} \mathrm{C}\right)$ were significantly $(\mathrm{p}>0.05)$ higher than crude $\mathrm{RSF}\left(41.57^{\circ} \mathrm{C}\right)$. On the other hand, the SMP of all liquid fractions were significantly $(p>0.05)$ lower than crude RSF. Low IV usually reflects high SMP due to the low content of unsaturated fatty acids (Jin et al., 2016). The IV of $\mathrm{F}_{2}-\mathrm{S}$ was the lowest $\left(27.57 \mathrm{~g} \mathrm{I}_{2} / 100 \mathrm{~g}\right.$ fat$)$, reflecting the highest SMP of $49.03^{\circ} \mathrm{C}$, while $\mathrm{F}_{1}$-L, on the contrary, exhibited the highest IV (48.49 $\mathrm{g} \mathrm{I}_{2} / 100 \mathrm{~g}$ fat) with the lowest SMP $\left(25.57^{\circ} \mathrm{C}\right)$. The results are in line with the results reported by Jin, Wang Su et al. (2017), where IVs of solid fractions decreased when the IVs of liquid fractions increased. This was further confirmed by the fatty acids, which showed variations in the content of SFAs and USFAs in all fractions (Table 2). All solid fractions contained significantly high levels of SFAs (long-chain fatty acid with a relatively high melting point) and were found as solid at room temperature, whereas the liquid fractions contained more USFAs (low melting fatty acids) which were melted completely at $<28^{\circ} \mathrm{C}$. The IV of $\mathrm{F}_{1}-\mathrm{S}(35.14 \mathrm{~g} \mathrm{I} / 100 \mathrm{~g}$ fat) was comparable with those of commercial CB (34.0 - $37.9 \mathrm{~g}$ $\mathrm{I}_{2} / 100 \mathrm{~g}$ fat) (Hamid and Damit, 2004; Muchiri et al., 2012; Yanty et al., 2012), but has higher SMP $\left(45.57^{\circ} \mathrm{C}\right)$ than $\mathrm{CB}\left(20.0-37.0^{\circ} \mathrm{C}\right)$ (Timms, 2005). This study also found that FFA content of all the fractions ranged from $1.62-2.25 \%$ which were significantly $(\mathrm{p}>0.05)$ lower than that of crude RSF (2.94\% as oleic acid). However, the fractionated fats are still not practically safe to be directly used in food processing purposes, therefore physical and chemical refining is needed to reduce the acidity of the fats to that desired for CB (Jahurul, Zaidul, Norulaini, Saleha, Kamaruzzaman et al., 2014; Jin et al., 2016).

\subsection{Solid fat content (SFC)}

The SFC is a useful tool to study the suitability of each fraction for a particular purpose in formulated foods (Sonwai et al., 2017). The SFC as a function of temperature for RSF and its fractions are given in Figure 3. SFC of crude RSF was found $66.9 \%$ at $10^{\circ} \mathrm{C}$ and decreased rapidly as the temperature increased before reaching $3.22 \%$ at $40^{\circ} \mathrm{C}$. It was predicted that the $\mathrm{SFC}$ increased in solid fractions and decreased in liquid fractions. This is due to the high content of high-melting TAGs in the solid fractions compared to the pure fat and the liquid fractions (Sonwai et al., 2017). All solid fractions $\left(\mathrm{F}_{1}-\mathrm{S}\right.$ and $\left.\mathrm{F}_{2}-\mathrm{S}\right)$ exhibited SFC higher than crude RSF at all temperatures (Figure 3). The SFC curve of $\mathrm{F}_{2}-\mathrm{S}$ was located well above compared to SFC curves of other fractions including crude RSF. Both $\mathrm{F}_{1}-\mathrm{S}$ and $\mathrm{F}_{2}$ $-\mathrm{S}$ showed slow decreasing of SFC at 10 and $15^{\circ} \mathrm{C}$, but sharp decreasing after $20^{\circ} \mathrm{C}$. However, it can be seen that $8.5 \%$ of SFC remained at $40^{\circ} \mathrm{C}$ in $\mathrm{F}_{2}-\mathrm{S}$, unlike $\mathrm{F}_{1}-\mathrm{S}$ for which only $5.18 \%$ of SFC remained at $40^{\circ} \mathrm{C}$. The $\mathrm{SFC}$ curve of $\mathrm{F}_{1}-\mathrm{S}$ was positioned above that of crude RSF but below that of $\mathrm{F}_{2}-\mathrm{S}$, demonstrating that it was a softer solid fraction compared to $\mathrm{F}_{2}-\mathrm{S}$. On the other hand, the SFC curve of liquid fraction $\left(\mathrm{F}_{1}-\mathrm{L}\right)$ was located below that of crude RSF, suggesting that it contained more liquid oil than crude RSF at any temperature, thereby indicating it as softest fraction compared to crude RSF and other fractions. The SFC curves of all fractions in this study were in line with the findings by Sonwai et al. (2017) and Jin, Zheng, Pembe et al. (2017), where the texture and specific melting behaviour can be enhanced with the increase of SFC in the solid fractions which make them suitable for food-applications such as cocoa butter alternatives. Jin, Zheng, Pembe et al. (2017) reported that at $35^{\circ} \mathrm{C}, \mathrm{CB}$ has melted completely and no solid remaining. Contrary to RSF and its fractions, there are solid remaining even at $40 \mathrm{oC}$. This shows that RSF fractions have higher stability and heat resistance at high temperature that could contribute to enhancing the quality of chocolate and has potential to be blend with CB without significantly altering the melting and crystallization temperature ranges or enthalpies, and SFC of natural cocoa butter (Kang et al., 2013). The results 
revealed that the solid fractions are suitable for $\mathrm{CBI}$, where it can be blended with $\mathrm{CB}$ to increase the hardness in terms of SFC. These fractions may be beneficial for use in tropical climates.

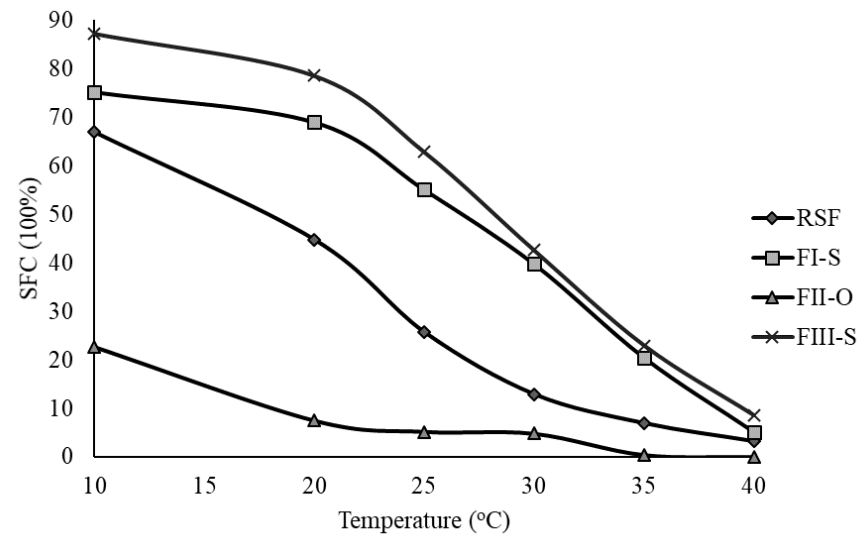

Figure 3. Solid fat content (\%), measured at $10-40^{\circ} \mathrm{C}$ of crude $\mathrm{RSF}$ and its fractions represents the average of duplicates and standard deviation.

\section{Conclusion}

Differences in physicochemical properties (fatty acids, IV, SMP, SFC, and FFA) were observed among crude RSF and its fractions. The solid $\left(\mathrm{F}_{2}-\mathrm{S}\right)$ fractionated from the first solid fraction $\left(\mathrm{F}_{1}-\mathrm{S}\right)$ showed better physicochemical properties as $\mathrm{CBI}$ in terms of high SMP and SFC as well as a significant improvement of fatty acids. The major fatty acids in $\mathrm{F}_{2}-\mathrm{S}$ were stearic, oleic, and arachidic acids. Moreover, the $\mathrm{F}_{2}-\mathrm{S}$ exhibited remarkable improvement of SFC as they were not shifted to $0 \%$ at body temperature, indicating a better melting resistance at high temperature. The $\mathrm{SFC}$ of $\mathrm{F}_{2}-\mathrm{S}$ at $20^{\circ} \mathrm{C}$ and $35^{\circ} \mathrm{C}$ were also found to be higher than that of $\mathrm{F}_{1}-\mathrm{S}$, indicating a harder solid fraction. Based on the results obtained in this study, $\mathrm{F}_{2}-\mathrm{S}$ could be used in formulating confectionery products by blending with $\mathrm{CB}$ or other fats such as palm oil mid-fraction or palm stearin.

\section{Conflict of Interest}

There is no conflict of interest.

\section{Acknowledgments}

This research was supported by the Centre for Research and Innovation, Universiti Malaysia Sabah (UMS) (GUG0336-1/2019).

\section{References}

American Oil Chemists' Society (AOCS). (2003). Official Methods and Recommended Practices of the American Oil Chemists' Society, 5th ed (Part 1, A-
C). Champaign, Illinois, USA: American Oil Chemists' Society (AOCS).

Chai, K.F., Adzahan, N.M., Karim, R., Rukayadi, Y. and Ghazali, H.M. (2018). Characteristics of fat, and saponin and tannin contents of 11 varieties of Rambutan (Nephelium lappaceum L.) seed. International Journal of Food Properties, 21(1), 1091-1106. doi.org/10.1080/10942912.2018.1479857

Chai, K.F., Adzahan, N.M., Karim, R., Rukayadi, Y. and Ghazali, H.M. (2019). Fat properties and antinutrient content of rambutan (Nephelium lappaceum L.) seed during solid-state fermentation of rambutan fruit. Food Chemistry, 274, 808-815. https:// doi.org/10.1016/j.foodchem.2018.09.065

Fiebig, H.J. and Lüttke, J. (2003). Solid fat content in fats and oils-determination by pulsed nuclear magnetic resonance spectroscopy. European Journal of Lipid Science and Technology, 105, 377-380. https://doi.org/10.1002/ejlt.200390076

Foubert, I., Vanrolleghem, P.A., Thas, O. and Dewettinckallization. Journal of Food Science, K. (2004). Influence of chemical composition on the isothermal cocoa butter cryst, 69(9), 478-487. https:// doi.org/10.1111/j.1365-2621.2004.tb09933.x

Gibon, V. (2006). Fractionation of lipids for use in food. Modifying lipids for use in food, 201-233. England: CRC Press. https:// doi.org/10.1533/9781845691684.2.201

Gunstone, F.D. (Ed.) (2011). Vegetable Oils in Food Technology Composition, Properties and Uses., p. 291-343. United Kingdom: Wiley-Blackwell. https:// doi.org/10.1002/9781444339925

Hamid, A. and Damit, A.A. (2004). Quality of Malaysian cocoa butter during storage. Journal of the Science of Food and Agriculture, 84(6), 513-516. https:// doi.org/10.1002/jsfa.1629

Issara, U., Zzaman, W. and Tajul, Y. (2014). Rambutan seed fat as a potential source of cocoa butter substitute in confectionary product. International Food Research Journal, 21(1), 25-31.

Jahurul, M.H.A., Zaidul, I.S.M., Norulaini, N.A., Sahena, F., Kamaruzzaman, B.Y., Ghafoor, K. and Omar, A.K.M. (2014). Cocoa butter replacers from blends of mango seed fat extracted by supercritical carbon dioxide and palm stearin. Food Research International, 65(Part C), 401-406. https:// doi.org/10.1016/j.foodres.2014.06.039

Jahurul, M.H.A., Zaidul, I.S.M., Norulaini, N.A., Sahena, F., Abedin, M.Z., Mohamed, A. and Omar, A.K.M. (2014). Hard cocoa butter replacers from mango seed fat and palm stearin. Food Chemistry, 
154 , $323-329$.

j.foodchem.2013.11.098

https://doi.org/10.1016/

Jin, J., Warda, P., Mu, H.Y., Zhang, Y.F., Jie, L., Mao, J.H., Xie, D., Huang, J.H., Jin, Q.Z. and Wang, X.G. (2016). Characteristics of mango kernel fats extracted from 11 China- specific varieties and their typically fractionated fractions. Journal of the American Oil Chemists' Society, 93(8), 1115-1125. https://doi.org/10.1007/s11746-016-2853-2

Jin, J., Wang, Y., Su, H., Warda, P., Xie, D., Liu, Y., Wang, X., Huang, J., Jin, Q. and X. Wang. (2017). Oxidative stabilities of mango kernel fat fractions produced by three-stage fractionation. International Journal of Food Properties, 20(11), 2817-2829. https://doi.org/10.1080/10942912.2016.1253096

Jin, J., Zheng, L., Pembe, W., Zhang, J., Xie, D., Wang, X., Huang, J., Jin, Q. and Wang, X. (2017). Production of sn-1,3-distearoyl-2-oleoyl-glycerolrich fats from mango kernel fat by selective fractionation using 2-methylpentane based isohexane. Food Chemistry, 234, 46-54. https:// doi.org/10.1016/j.foodchem.2017.04.165

Jia, C-H., Shin, J-A. and Lee, K-T. (2019). Evaluation model for cocoa butter equivalents based on fatty acid compositions and triacylglycerol patterns. Food Science and Biotechnology, 28, 1649-1658. https:// doi.org/10.1007/s10068-019-00630-8

Kang, K.K., Kim, S., Kim, I.H., Lee, C. and Kim, B.H. (2013). Selective enrichment of symmetric monounsaturated triacylglycerols from palm stearin by double solvent fractionation. LWT-Food Science and Technology, 51(1), 242-252. https:// doi.org/10.1016/j.lwt.2012.08.009

Kadivar, S., Clercq, N. De., Mokbul, M. and Dewettinck, K. (2016). Influence of enzymatically produced sunflower oil based cocoa butter equivalents on the phase behavior of cocoa butter and quality of dark chocolate. LWT-Food Science and Technology, 66, 48-55. https://doi.org/10.1016/j.lwt.2015.10.006

Kellens, M., Gibon, V., Hendrix, M. and Greyt, W. De. (2007). Palm oil fractionation. European Journal of Lipid Science and Technology, 109(4), 336-349. https://doi.org/10.1002/ejlt.200600309

Latip, R.A., Lee, Y.Y., Tang, T.K., Phuah, E.T., Lee, C.M., Tan, C.P. and Lai, O.M. (2013) Palm-based diacylglycerol fat dry fractionation: effect of crystallisation temperature, cooling rate and agitation speed on physical and chemical properties of fractions. PeerJ, 1, e72. https://doi.org/10.7717/ peerj. 72

Lakum, R. and Sonwai, S. (2018). Production of transfree margarine fat by enzymatic interesterification of soybean oil, palm stearin and coconut stearin blend. International Journal of Food Science and Technology, 53(12), 2761-2769. https:// doi.org/10.1111/ijfs. 13888

Lourith, N., Kanlayavattanakul, M., Mongkonpaibool, K., Butsaratrakool, T. and Chinmuang, T. (2016). Rambutan seed as a new promising unconventional source of specialty fat for cosmetics. Industrial Crops and Products, 83, 149-154. https:// doi.org/10.1016/j.indcrop.2015.12.045

Lipp, M. and Anklam, E. (1998). Review on cocoa butter and alternatives for use in chocolate. Part A: Compositional data. Journal of Food Chemistry, 62 (1), 73-97. https://doi.org/10.1016/S0308-8146(97) 00160-X

Momeny, E., Vafaei, N. and Ramli, N. (2013). Physicochemical properties and antioxidant activity of a synthetic cocoa butter equivalent obtained through modification of mango seed oil. International Journal of Food Science and Technology, 48(7), 1549-1555. https:// doi.org/10.1111/ijfs.12125

Mu, H.Y., Zhang, H.J., Li, Y., Zhang, Y., Wang, X.S., Jin, Q.Z. and Wang, X.G. (2016). Enrichment of DPAn-6 and DHA from Schizochytrium sp. oil by low-temperature solvent crystallization. Industrial and Engineering Chemistry Research, 55, 737-746. https://doi.org/10.1021/acs.iecr.5b03766

Muchiri, D.R, Mahungu, S.M. and Gituanja, S.N. (2012). Studies on mango (Mangiferaindica L.) kernel fat of some Kenyan varieties in Meru. Journal of the American Oil Chemists' Society, 89(9), 1567-1575. https://doi.org/10.1007/s11746-012-2054-6

Norlia, M.I., Roshazita, C.A., Nuraiti, T.I., Salwa, M.Z.M. and Fatimah, M.S.S. (2011). Preparation and characterisation of activated carbon from rambutan seed (Nephelium lappaceum) by chemical activation. Empowering Science, Technology and Innovation towards a Better Tomorrow, 17, 184-191.

Naik, B. and Kumar, V. (2014). Cocoa Butter and Its Alternatives: A Review. Journal of Bioresource Engineering and Technology, 2(1), 7-17.

Senanayake, S.P.J.N. and Shahidi, F. (2005). Modification of Fats and Oils via Chemical and Enzymatic Methods. In Shahidi, F. (Ed.) Bailey's industrial oil and fat products. 6th ed., p. 555-584. New York, USA: Wiley. https:// doi.org/10.1002/047167849X.bio062

Shahidi, F. (2005). Bailey's industrial oil and fat products. 6th ed., p. 159-173. New York, USA: Wiley. https://doi.org/10.1002/047167849X

Sirisompong, W., Jirapakkul, W. and Klinkesorn, U. 
(2011). Response surface optimization and characteristics of rambutan (Nephelium lappaceum L.) kernel fat by hexane extraction. LWT-Food Science and Technology, 44(9), 1946-1951. https:// doi.org/10.1016/j.lwt.2011.04.011

Sonwai, S. and Ponprachanuvut, P. (2012). Characterization of physicochemical and thermal properties and crystallization behavior of krabok (Irvingia Malayana) and Rambutan seed fats. Journal of Oleo Science, 61(12), 671-679. https:// doi.org/10.5650/jos.61.671

Solís-Fuentes, J.A., Camey-Ortíz, G., Hermández-Medel, M.R., Pérez-Mendoza, F. and Carmen, D. (2010). Composition, phase behavior and thermal stability of natural edible fat from Rambutan (Nephelium lappaceum L.) seed. Bioresource Technology, 101 (2), 799-803. https://doi.org/10.1016/ j.biortech.2009.08.031

Sonwai, S., Rungprasertphol, P., Nantipipat, N., Tungvongcharoan, S. and Laiyangkoon, N. (2017). Characterization of coconut oil fractions obtained from solvent fractionation using acetone. Journal of Oleo Science, 66(9), 951-961. https:// doi.org/10.5650/jos.ess 16224

Smith, K.W. (2001). Cocoa butter and cocoa butter equivalents. In Gunstone, F.D. (Eds.) Structured and Modified Lipids., p. 401-422. New York: Marcel Dekker Inc.

Timms, R.E. (2005). Fractional crystallization - the fat modification process for the $21^{\text {st }}$ century. European Journal of Lipid Science and Technology, 107(1), 48 -57. https://doi.org/10.1002/ejlt.200401075

Tchobo, F.P., Piombo, G., Pina, M., Soumanou, M.M., Villeneuve, P. and Sohounhloue, D.C.K. (2009). Enzymatic synthesis of cocoa butter equivalent through transesterification of Pentadesma butyracea butter. Journal of Food Lipids, 16(4), 605-617. https://doi.org/10.1111/j.1745-4522.2009.01169.x

Yanty, N.A.M., Jalaldeen, M.N.M., Kamariah, L. and Hasanah, M.G. (2013). Physicochemical characterisation of the fat from red-skin rambutan (Nephellium lappaceum L.) seed. Journal of Oleo Science, 62(6), 335-343. https://doi.org/10.5650/ jos. 62.335

Yanty, N.A.M., Marikkar, J.M.N. and Miskandar, M.S. (2012). Comparing the thermo-physical characteristics of lard and selected plant fats. Grasas $y$ Aceites, 63, 328-334. https://doi.org/10.3989/ gya.023712 